\title{
Ansiedade no Período Pré-Operatório de Cirurgias de Mama: Estudo Comparativo entre Pacientes com Suspeita de Câncer e a Serem Submetidas a Procedimentos Cirúrgicos Estéticos*
} Preoperative Anxiety in Surgeries of the Breast: A Comparative Study between
Patients with Suspected Breast Cancer and that Undergoing Cosmetic Surgery

Maria Luiza Melo Alves', Adriana Jucá Pimentel', Álvaro Antônio Guaratini, TSA ${ }^{3}$, José Álvaro Marques Marcolino4, Judymara Lauzi Gozzani, TSA ${ }^{5}$, Ligia Andrade da Silva Telles Mathias, TSA ${ }^{6}$

RESUMO

Alves MLM, Pimentel AJ, Guaratini AA, Marcolino JAM, Gozzani JL, Mathias LAST - Ansiedade no Período Pré-Operatório de Cirurgias de Mama: Estudo Comparativo entre Pacientes com Suspeita de Câncer e a Serem Submetidas a Procedimentos Cirúrgicos Estéticos.

JUSTIFICATIVA E OBJETIVOS: A avaliação da ansiedade não faz parte da rotina da avaliação pré-anestésica (APA), o que faz com que situações especiais em que o estado emocional dos pacientes possa estar alterado, passem despercebidas pelo anestesiologista. Este estudo visou comparar, no momento da APA ambulatorial, fatores de risco, intensidade e prevalência de ansiedade em pacientes com suspeita de câncer de mama e a serem submetidas a procedimentos cirúrgicos estéticos de mama.

MÉTODO: Após aprovação pelo Comitê de Ética, foram estudadas, no ambulatório de APA, 114 pacientes, ASA I ou II, idade $\geq 14$ anos, divididas nos grupos: GmamA - pacientes com suspeita de câncer de mama; GPLAST - pacientes a serem submetidas à cirurgia plástica estética. Após consentimento esclarecido, as pacientes responderam o teste de avaliação de ansiedade (IDATE — Inventário de Ansiedade Traço-Estado) antes da avaliação pré-anestésica. Foram analisados: dados sociodemográficos; experiência com procedimentos cirúrgicos anteriores; número e percentual de pacientes com ansiedade baixa, moderada e alta (IDATE I e II); mediana das pontuações das escalas IDATE I e II.

RESULTADOS: Os grupos foram homogêneos em relação aos dados sociodemográficos e experiência com procedimentos cirúrgi-

\footnotetext{
${ }^{*}$ Recebido de (Received from) Irmandade da Santa Casa de Misericórdia de São Paulo (ISCMSP), São Paulo, SP

1. Docente da Faculdade de Ciências Médicas da Universidade de Pernambuco; Pós-Graduanda da Faculdade de Ciências Médicas da Santa Casa de São Paulo 2. Médica Residente da Cabeça e Pescoço da Beneficência Portuguesa de São Paulo

3. Médico Assistente, Hospital Central da ISCMSP; Mestre em Medicina; Doutorando da Faculdade de Ciências Médicas da Santa Casa de São Paulo; Coresponsável do CET-SBA, ISCMSP

4. Médico Assistente, Hospital Central da ISCMSP; Professor Adjunto de Psiquiatria da Faculdade de Ciências Médicas da Santa Casa de São Paulo 5. Mestre em Biologia Molecular; Doutora em Medicina; Responsável pelo Grupo de Dor da ISCMSP

6. Diretora do Serviço e Disciplina de Anestesiologia, ISCMSP e Faculdade de Ciências Médicas da Santa Casa de São Paulo; Responsável pelo CET-SBA, ISCMSP

Apresentado (Submitted) em 10 de abril de 2006

Aceito (Accepted) para publicação em 08 de dezembro de 2006

Endereço para correspondência (Correspondence to):

Dra. Lígia Andrade da Silva Telles Mathias

Alameda Campinas, 139/4

01404-000 São Paulo, SP

E-mail: rtimao@uol.com.br
}

(c) Sociedade Brasileira de Anestesiologia, 2007 cos anteriores. Observou-se diferença significativa dos níveis e prevalência de ansiedade-estado (IDATE I). Não foram identificados fatores de risco para ansiedade-estado e ansiedade-traço.

CONCLUSÕES: As pacientes com suspeita de câncer de mama a serem submetidas à retirada de nódulo ou tecido mamário para diagnóstico apresentaram níveis e prevalência de ansiedade-estado alta maiores do que as pacientes a serem submetidas a mamoplastias; os níveis e a prevalência de ansiedade-traço foram similares nos dois grupos e não foram identificados fatores de risco para ansiedade-estado e ansiedade-traço.

Unitermos: AVALIAÇÃO PRÉ-ANESTÉSICA: estado psicológico; ClRURGIA, Ginecológica, Plástica: mama.

\section{SUMMARY}

Alves MLM, Pimentel AJ, Guaratini AA, Marcolino JAM Gozzani JL, Mathias LAST - Preoperative Anxiety in Surgeries of the Breast: A Comparative Study between Patients with Suspected Breast Cancer and those Undergoing Cosmetic Surgery.

BACKGROUND AND OBJECTIVES: Evaluation of anxiety is not part of the routine pre-anesthetic evaluation (APA). Therefore, special situations in which patients might present altered mood will go unnoticed by the anesthesiologist. The objective of this study was to compare, at the moment of the outpatient basis APA, the risk factors, severity, and prevalence of anxiety in patients with suspected breast cancer and those undergoing cosmetic surgery of the breast.

METHODS: After approval by the Ethics Committee, 114 patients, ASA I or II, 14 years or older, were studied at the APA clinic; they were divided in two groups: GMAMA - patients with suspected breast cancer; GPLAST - patients undergoing cosmetic surgery. After signing the informed consent, patients answered the anxiety evaluation test (STAI - State-Trait Anxiety Inventory) before the preanesthetic evaluation. The following parameters were analyzed: socio-demographic data; prior experience with surgical procedures; number and percentage of patients with low, moderate, or high anxiety (STAI I and II); and median of the STAI I and II scores.

RESULTS: Both groups were homogenous regarding the sociodemographic data and prior experience with surgical procedures. There was a significant difference in the levels and prevalence of anxiety-state (STAI I). No risk factors for anxiety-state and anxietytrait were identified.

CONCLUSIONS: Patients with suspected breast cancer scheduled for nodulectomy or removal of breast tissue for diagnosis, had higher levels and prevalence of anxiety-state than patients undergoing mammaplasty; the levels and prevalence of anxiety-trait were similar in both groups; no risk factors for anxiety-state and anxiety-trait were identified.

Key Words: PREANESTHETIC EVALUATION: psychological status; SURGERY, Gynecologic, Plastic: breast 


\section{INTRODUÇÃO}

números são os fatores identificados como responsáveis pela ansiedade que cerca o momento do ato anestésicocirúrgico: preocupação com lesões que possam ocorrer durante o procedimento cirúrgico, receio de dor no período pós-operatório, separação da família, perda da independência, medo de ficar incapacitado, medo de não acordar mais, medo de acordar no meio de uma anestesia, medo do diagnóstico e das complicações ${ }^{1-4}$.

Altos níveis de ansiedade pré-operatória foram associados à natureza de experiências anestésicas prévias, histórico de câncer, tabagismo, desordens psiquiátricas, percepção negativa do futuro, sintomas depressivos moderados a intensos e presença de dor moderada ou intensa ${ }^{5-7}$.

Com relação especificamente às pacientes com câncer de mama, há várias publicações sobre a condição emocional antes, durante e após o tratamento clínico e/ou cirúrgico ${ }^{8-11}$. No entanto, não foram encontrados estudos sobre a ansiedade de pacientes com suspeita de câncer de mama no momento da avaliação pré-anestésica (APA) previamente à biópsia, quando preocupações ligadas à feminilidade, maternidade e sexualidade possam estar presentes, já que o seio é um órgão repleto de simbolismo para a mulher 12-14. Outro grupo de pacientes cirúrgicos que pode apresentar distúrbios psicológicos temporários ou duradouros em incidência elevada são os pacientes a serem submetidos a procedimentos cirúrgicos estéticos da mama, sendo considerados fatores associados a esses distúrbios: faixa etária jovem, sexo masculino, expectativas irreais sobre o procedimento, histórico de depressão, ansiedade ou distúrbios de personalidade ${ }^{15,16}$.

Os estudos não discutem a situação emocional das pacientes a serem submetidas aos procedimentos cirúrgicos estéticos da mama ou pacientes com suspeita de câncer de mama, no momento da avaliação pré-anestésica. Este foi o motivo desta pesquisa, que visou comparar, no momento da APA ambulatorial, a intensidade e a prevalência da ansiedade e os fatores de risco de ansiedade dessas pacientes.

\section{MÉTODO}

Após aprovação pelo Comitê de Ética da Universidade de Pernambuco, foram incluídas neste estudo prospectivo comparativo, realizado durante período de 18 meses, pacientes do ambulatório de APA a serem submetidas à exérese de nódulo ou tecido mamário para diagnóstico por suspeita de câncer de mama e pacientes a serem submetidas a procedimentos cirúrgicos estéticos de mama.

Todas as pacientes eram do sexo feminino, estado físico ASA I ou II, com idade maior ou igual a 14 anos. Foram excluídas do estudo pacientes: com graves deficiências visuais ou auditivas; analfabetas ou que não tinham domínio da língua portuguesa; com distúrbios intelectuais evidentes; em uso de substâncias psicoativas; com doenças do sistema nervoso central (neurológicas ou psiquiátricas); com tumor de mama recidivado e agendadas para reconstrução mamária pós-mastectomia.

As pacientes foram distribuídas em dois grupos: GMAMA composto por pacientes com suspeita de câncer de mama a serem submetidas a exérese de nódulo ou tecido mamário para diagnóstico; GPLAST - composto por pacientes a serem submetidas a procedimentos cirúrgicos estéticos de mama, sem suspeita de câncer.

Para a avaliação da ansiedade, foi utilizado o Inventário de Ansiedade Traço-Estado (IDATE) ${ }^{17}$, que é composto por duas escalas: escala de estado de ansiedade IDATE I (ansiedade-estado) com 20 afirmações que indicam como os indivíduos se sentem em um determinado momento; e escala de traço de ansiedade IDATE II (ansiedade-traço) também com 20 afirmações, que descrevem como os indivíduos se sentem normalmente. A cada um dos itens das duas escalas é atribuído um escore de 1 a 4 e o escore total pode variar de 20 (mínimo) a 80 (máximo) ${ }^{17-19}$.

No momento da avaliação pré-anestésica ambulatorial, foi obtido o consentimento esclarecido das pacientes para participação no estudo. A seguir as pacientes responderam ao IDATE e a uma ficha de avaliação pré-anestésica que constava de duas partes, a serem preenchidas pelo paciente e pelo anestesiologista, respectivamente. Depois de preenchidos os instrumentos, todas as pacientes foram submetidas à APA. Todos os procedimentos da pesquisa foram realizados apenas pelo anestesiologista responsável pelo estudo. Os escores considerados ponto de corte para considerar os pacientes com ansiedade baixa, moderada e alta foram, de acordo com a literatura 2,17,19-21: ansiedade alta $\geq$ quartil 75 ; ansiedade moderada: entre os quartis 75 e 25; ansiedade baixa < quartil 25.

Foram analisadas as variáveis sociodemográficas (idade, faixa etária, estado civil, situação ocupacional atual), as experiências com cirurgias anteriores ou não e os escores da escala IDATE I e II.

$\mathrm{Na}$ comparação entre os resultados referentes à idade foi utilizado o teste $t$ de Student não-pareado. Na comparação entre os resultados referentes às outras variáveis foram utilizado os testes Exato de Fisher, de Qui-quadrado para tabelas maiores que $2 \times 2$ e de Mann-Whitney. Foi considerada diferença estatística significativa quando $p<0,05$. Os testes utilizados fazem parte do sistema computacional Statistical Package for the Social Sciences (SPSS) for Windows 14.

\section{RESULTADOS}

A amostra final ficou constituída por 114 pacientes no período pré-operatório, sendo 53 (46,5\%) delas com suspeita de câncer de mama (GMAmA) e 61 (53,5\%) a serem submetidas a procedimentos cirúrgicos estéticos de mama (GPLAST). Os dados sociodemográficos (idade, estado civil e situação ocupacional atual) e os relativos à experiência com procedimentos cirúrgicos anteriores, assim como os resultados dos testes estatísticos, encontram-se na tabela I. 


\section{ANSIEDADE NO PERÍODO PRÉ-OPERATÓRIO DE CIRURGIAS DE MAMA: ESTUDO COMPARATIVO ENTRE PACIENTES}

COM SUSPEITA DE CÂNCER E A SEREM SUBMETIDAS A PROCEDIMENTOS CIRÚRGICOS ESTÉTICOS

Tabela I - Dados Sociodemográficos e Relativos à Experiência com Procedimentos Cirúrgicos Anteriores dos Pacientes dos Grupos Gmama e GPLAST

\begin{tabular}{|c|c|c|c|c|c|}
\hline \multirow[b]{2}{*}{ Variáveis } & \multicolumn{2}{|c|}{ Gmama } & \multicolumn{2}{|c|}{ GPLAST } & \multirow[b]{2}{*}{$\mathrm{p}$} \\
\hline & Freqüência & $\%$ & Freqüência & $\%$ & \\
\hline \multicolumn{6}{|l|}{ Faixa etária (anos) } \\
\hline 14 a 30 & 9 & 16,9 & 15 & 24,6 & $0,5677^{1}$ \\
\hline 31 a 50 & 27 & 50,9 & 30 & 49,2 & \\
\hline Com companheiro & 28 & 52,8 & 22 & 36,1 & $0,0919^{2}$ \\
\hline Sem companheiro & 25 & 47,2 & 39 & 62,3 & \\
\hline \multicolumn{6}{|c|}{ Situação ocupacional atual } \\
\hline Com renda & 46 & 86,8 & 49 & 80,3 & $0,4301^{2}$ \\
\hline $\operatorname{Sim}$ & 45 & 84,9 & 48 & 78,7 & $0,4519^{2}$ \\
\hline Não & 7 & 13,2 & 12 & 19,7 & \\
\hline Não respondeu & 1 & 1,88 & 1 & 1,63 & \\
\hline
\end{tabular}

GMAMA - grupo com suspeita de câncer de mama; GPLAST — grupo de cirurgia plástica $\mathrm{p}^{1}=$ teste de Qui-quadrado para tabela maior que $2 \times 2 ; \mathrm{p}^{2}=$ teste Exato de Fisher

Os grupos foram homogêneos em relação aos dados demográficos e experiências com procedimentos cirúrgicos anteriores.

De acordo com os critérios estabelecidos no método 2,17,20,21, os pontos de corte foram:

- IDATE I: ansiedade baixa: $\leq 35$; ansiedade moderada: 36 a 46 ; ansiedade alta: $\geq 47$.

- IDATE II: ansiedade baixa: $\leq 32$; ansiedade moderada: 33 a 41 ; ansiedade alta: $\geq 42$.

$\mathrm{Na}$ tabela II encontram-se os valores das médias, desviospadrão, medianas, percentis 25 e 75 das pontuações da escala de ansiedade IDATE I e IDATE II dos pacientes dos grupos Gmama e Gplast e os resultados do teste de MannWhitney.
Observou-se diferença estatística significativa entre os grupos GmAMA e GpLAST $(p=0,0406)$ na comparação das pontuações apenas na escala de ansiedade IDATE I (teste de Mann-Whitney).

Os resultados do número total e percentual de pacientes com ansiedade baixa, moderada e alta (IDATE I e II) dos dois grupos estudados e o valor do teste de Mann-Whitney, constam das tabelas III e IV, respectivamente.

Foi observada diferença estatística significativa $(p=0,043)$ da prevalência dos diversos níveis de ansiedade-estado (IDATE I) entre GmAMA e GPLAST (teste de Mann-Whitney).

Não foi evidenciada diferença significativa $(p=0,776)$ da prevalência dos diversos níveis de ansiedade-traço (IDATE II) entre esses grupos (teste de Mann-Whitney).

Tabela II - Valores das Medianas e Percentis 25 e 75 das Pontuações do IDATE I (ansiedade-estado) e IDATE II (ansiedadetraço) dos Grupos Estudados

\begin{tabular}{|c|c|c|c|c|c|c|}
\hline & \multicolumn{3}{|c|}{ IDATE I — Estado } & \multicolumn{3}{|c|}{ IDATE II — Traço } \\
\hline & GMAMA & GPLAST & $p$ & Gmama & GPLAST & $p$ \\
\hline Média \pm DP & $42,3 \pm 7,7$ & $38,0 \pm 8,2$ & & $39,1 \pm 8,1$ & $37,6 \pm 8,3$ & \\
\hline Mediana & 42,0 & 38,0 & 0,0406 & 39,5 & 36,0 & 0,7843 \\
\hline Percentil 25 & 37,0 & 33,0 & & 32,0 & 33,0 & \\
\hline
\end{tabular}

GMAMA - grupo com suspeita de câncer de mama; GPLAST — grupo de cirurgia plástica $\mathrm{p}=$ resultado do teste de Mann-Whitney 
Tabela III — Número Total e Percentual de Pacientes com Ansiedade-Estado Baixa, Moderada e Alta, dos Dois Grupos Estudados, segundo o IDATE I

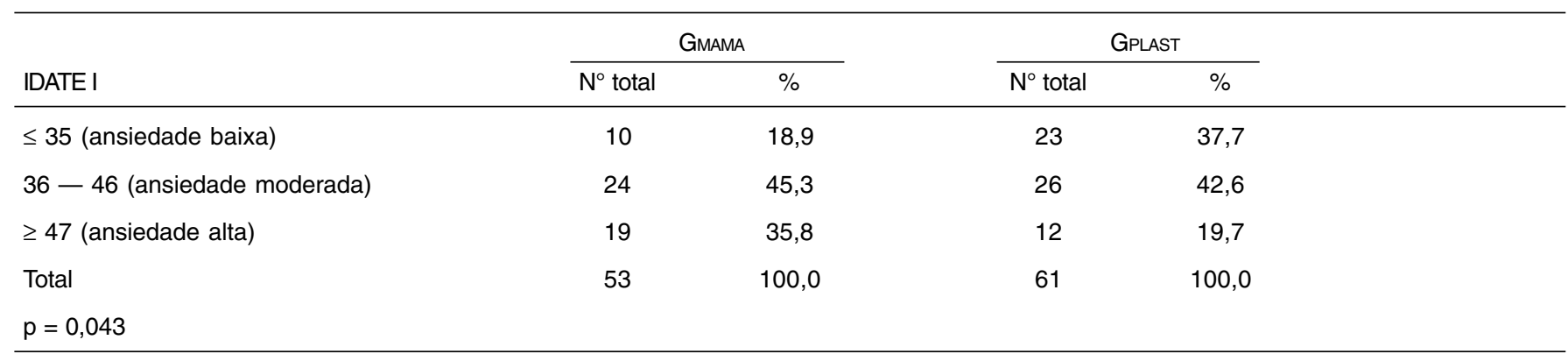

GMAMA - grupo com suspeita de câncer de mama; GPLAST — grupo de cirurgia plástica $\mathrm{p}=$ resultado do teste de Mann-Whitney

Tabela IV - Número Total e Porcentagem de Pacientes com Ansiedade-Traço Baixa, Moderada e Alta, dos Dois Grupos Estudados, segundo o IDATE II

\begin{tabular}{|c|c|c|c|c|}
\hline$\leq 32$ (ansiedade baixa) & 14 & 26,4 & 15 & 24,6 \\
\hline $33-41$ (ansiedade moderada) & 24 & 45,3 & 31 & 50,8 \\
\hline$\leq 42$ (ansiedade alta) & 15 & 28,3 & 15 & 24,6 \\
\hline
\end{tabular}

GMAMA - grupo com suspeita de câncer de mama; GPLAST — grupo de cirurgia plástica

$\mathrm{p}=$ resultado do teste de Mann-Whitney

Nos pacientes dos Gmama e Gplast foi realizada análise de cada dado sociodemográfico e da experiência ou não com procedimentos cirúrgicos anteriores, para verificar a existência de fator de risco de nível alto de ansiedade-estado (IDATE I). Não foi observada diferença significativa com relação à prevalência de nível alto de ansiedade-estado para qualquer das variáveis analisadas nos dois grupos estudados.

\section{DISCUSSÃO}

"O medo do desconhecido" 2,22-24 tem sido apontado como a maior fonte de ansiedade entre os pacientes que realizam avaliação pré-anestésica em regime ambulatorial. No entanto, a avaliação específica da ansiedade, como um item separado, não faz parte da rotina da APA tanto ambulatorial, como nos pacientes internados, o que faz com que situações especiais em que o estado emocional dos pacientes possa estar alterado, pela própria doença e/ou por outros motivos (problemas familiares, crianças na fase pré-escolar, possibilidade de mutilações), passem despercebidas pela equipe anestésico-cirúrgica ${ }^{2,4,25-27}$.

A escolha do IDATE para ser aplicada neste estudo deveuse à qualidade do instrumento (auto-avaliação e de fácil compreensão pelo leigo) e por ser considerada uma escala padrão-ouro 20,21,23,28-37.

As médias do estado e traço de ansiedade (IDATE I e II) encontradas no presente estudo aproximam-se dos valores encontrados na literatura, em estudos realizados no período pré-operatório, mas não no momento da APA ${ }^{2,6,38}$. No presente estudo, a prevalência de ansiedade moderada e alta foi de $89,1 \%$ no GMAMA e de $62,3 \%$ no GPLAST, valores elevados para ambos os grupos, refletindo talvez a importância do momento da APA, próxima do ato cirúrgico. Ele mostra também, conforme identificado na análise estatística, que as pacientes do GMAMA apresentaram maior prevalência de ansiedade alta e valores mais altos do que as do GPLAST, sugerindo que a iminência de um diagnóstico de câncer induz com mais freqüência um nível alto de ansiedade do que uma intervenção cirúrgica estética.

Os resultados não revelaram diferença quanto ao traço de ansiedade entre os dois grupos, como seria esperado, pois ele reflete uma tendência estável do indivíduo a respeito da ansiedade, menos sensível a mudanças com relação às situações ambientais ${ }^{39}$.

Estudos de seguimento de pacientes com câncer de mama submetidas a mastectomias relatam níveis anormais de ansiedade em $20 \%$ a $25 \%$ das mesmas 40,41 . 
Magalhães Filho e col. ${ }^{7}$ encontraram prevalência de ansiedade em $40,6 \%$ de pacientes com diferentes tipos de câncer, submetidos à escala hospitalar de ansiedade e depressão (HAD), no momento da APA ambulatorial.

Os resultados observados no presente estudo para o grupo de pacientes com suspeita de câncer de mama, com relação à prevalência de ansiedade, situam-se dentro dos valores encontrados na literatura, utilizando métodos diversos, para pacientes com câncer em tratamento clínico e para pacientes com e sem câncer no período pré-operatório, salientando-se que nenhum desses estudos avaliou os pacientes no momento da APA ambulatorial ${ }^{2,6,12}$.

$\mathrm{O}$ estudo de Yumi e col. ${ }^{42}$ que comparou o estado de ansiedade em pacientes que foram submetidas à exérese de tumor mamário, mostrou que as pacientes que reprimiam sua ansiedade pré-operatória ficavam mais ansiosas, deprimidas e confusas após receberem o diagnóstico de câncer, em um grau muito mais elevado que as do grupo que haviam expressado abertamente suas emoções. O presente estudo não avaliou a ansiedade das pacientes após o diagnóstico de câncer, o que deixa espaço para prosseguir com outros estudos.

Quanto ao grupo de pacientes a serem submetidas à intervenção cirúrgica estética, não foram encontrados dados comparativos na literatura.

Smith e col. ${ }^{43}$ verificaram que o traço de ansiedade mais que o estado de ansiedade afeta as necessidades anestésicas intra-operatórias e sugerem que os anestesiologistas deveriam basear a dose de indução anestésica no nível de ansiedade pré-operatória dos pacientes. No presente estudo esses aspectos não foram avaliados.

Não foi possível identificar-se fatores de risco para ansiedade alta. Esses resultados não coincidem com a literatura, que refere prevalências maiores de ansiedade em pacientes jovens, com baixa escolaridade, maior renda e sem companheiro ${ }^{6,44-48}$. Os dados da literatura referemse, todavia, à comparação entre pacientes com e sem ansiedade e o atual estudo compara diferentes níveis de ansiedade.

Um novo modelo de APA que se preocupe mais com as dimensões psicossociais dos pacientes, permitindo com isso um melhor diagnóstico e tratamento dos distúrbios de ansiedade, impõe-se no momento. A abordagem ampla e precoce do paciente no período pré-operatório tem como vantagem a possibilidade de detecção dos indivíduos com distúrbios de ansiedade, cujas conseqüências aparecem tanto no intra- quanto no pós-operatório. Deve ser objeto de futuras pesquisas 0 aprofundamento da questão referente à abordagem e terapia desses pacientes, uma vez que atender às questões emocionais corresponde a melhorar de forma substancial o tratamento clínico.

Este estudo demonstrou, em pacientes com suspeita de câncer de mama, a importância de se acrescentar a verificação do grau de ansiedade à avaliação pré-anestésica ambulatorial.

\section{Preoperative Anxiety in Surgeries of the Breast: A Comparative Study between Patients with Suspected Breast Cancer and that Undergoing Cosmetic Surgery}

Maria Luiza Melo Alves, M.D.; Adriana Jucá Pimentel, M.D.; Álvaro Antônio Guaratini, TSA, M.D.; José Álvaro Marques Marcolino, M.D.; Judymara Lauzi Gozzani, TSA, M.D.; Ligia Andrade da Silva Telles Mathias, TSA, M.D.

\section{INTRODUCTION}

There are several factors responsible for the anxiety connected with anesthesia/surgery: concern about lesions that might be incurred during the procedure, fear of postoperative pain, separation from the family, loss of independence, fear of becoming disabled, not waking up any more, waking up in the middle of the surgery, the diagnosis, and complications ${ }^{1-4}$.

High preoperative anxiety levels were associated with the nature of prior experience with anesthesia, history of cancer, smoking, psychiatric disorders, negative outlook about the future, moderate to severe symptoms of anxiety, and presence of moderate or severe pain ${ }^{5-7}$.

Regarding patients with breast cancer, there are several reports in the literature on the emotional status of patients before, during, and after the clinical and/or surgical treatment ${ }^{8-11}$. However, we did not find in the literature any studies on anxiety of patients with suspected breast cancer at the time of the preanesthetic evaluation (APA), before the biopsy, when concerns about femininity, maternity, and sexuality might be present, since the breast is full of symbolism for women ${ }^{12-14}$.

Another group of patients that might show a high incidence of temporary or lasting psychological disturbances are those undergoing cosmetic surgeries of the breast, and the associated factors include: young patient, male, unreal expectations about the procedure, and history of depression, anxiety, or personality disorders ${ }^{15,16}$.

Those studies did not discuss the emotional status of patients undergoing cosmetic surgeries of the breast or patients with suspected breast cancer at the time of the preanesthetic evaluation. The objective of this study was to compare the severity and prevalence of anxiety at the time of the outpatient basis APA, and the risk factors for anxiety in those patients.

\section{METHODS}

After approval by the Ethics Committee of the Universidade de Pernambuco, patients of the APA clinic with suspected breast cancer scheduled for diagnostic nodulectomy or re- 
moval of breast tissue, and patients scheduled for cosmetic breast surgery were included in this comparative, prospective study during an 18-month period.

Patients were female, ASA physical status I or II, 14 years or older. Criteria for exclusion included: patients with severe visual or hearing deficiencies; illiterate or those that did not understand Portuguese; those with intellectual disturbances; taking psychoactive drugs; with central nervous system disorders (neurological or psychiatric); with recurrent breast tumor; and those scheduled for breast reconstruction after mastectomy.

Patients were divided in two groups: GMAmA - patients with suspected breast cancer undergoing nodulectomy or removal of breast tissue for diagnosis; GPLAST — patients undergoing cosmetic breast surgery.

The State-Trait Anxiety Inventory (STAI) ${ }^{17}$ was used to evaluate anxiety. It is composed of two scales: scale of anxietystate, STAI I, with 20 affirmations that indicate how individuals feel at a specific moment; and scale of anxiety-trait, STAI II, also with 20 affirmations that describe how individuals usually feel. Each item of the two scales receives a score from 1 to 4 , and the total score varies from 20 (minimum) to 80 (maximum) ${ }^{17-19}$.

Patients signed an informed consent at the time of the outpatient basis preanesthetic evaluation. They answered the STAI and a preanesthetic evaluation form composed of two parts, to be filled by the patient and the anesthesiologist. Afterwards, patients were submitted to the APA. Every procedure of the study was performed only by the anesthesiologist responsible for the study.

The cutting points to consider a patient as having mild, moderate, or severe anxiety were, according to the literature ${ }^{2,17,19-21}$ : severe anxiety $\geq 75^{\text {th }}$ percentile; moderate anxiety: between the $75^{\text {th }}$ and $25^{\text {th }}$ percentiles; and mild anxiety $<25^{\text {th }}$ percentile.

Socio-demographic data (age, marital status, current occupation), prior surgical experience, and the scores of the STAI I and II were analyzed.

Non-paired test $t$ Student was used to compare the results regarding age. The other variables were analyzed by the Fisher Exact test, Chi-square test for tables greater than $2 \times 2$, and the Mann-Whitney test. A $p<0.05$ was considered statistically significant. The tests used are part of the Statistical Package for the Social Sciences (SPSS) for Windows 14.

\section{RESULTS}

The final study population was composed of 114 patients in the preoperative period; $53(46.5 \%)$ were suspected of having breast cancer (GMAMA) and 61 (53.5\%) were scheduled for cosmetic surgeries of the breast (GPLAST).

Table I shows the socio-demographic data (age, marital status, and occupation) and those regarding previous surgical experience, as well as the results of the statistical tests.

Both groups were homogenous regarding the demographic data and past experience with surgical procedures.

Table I - Socio-Demographic Data Regarding Prior Surgical Experience of Patients in GmAMA and GPLAST

\begin{tabular}{|c|c|c|c|c|c|}
\hline \multirow[t]{2}{*}{ Variables } & \multicolumn{2}{|c|}{ GMAmA } & \multicolumn{2}{|c|}{ GPLASt } & \multirow[b]{2}{*}{$p$} \\
\hline & Frequency & $\%$ & Frequency & $\%$ & \\
\hline \multicolumn{6}{|l|}{ Age group (years) } \\
\hline 14 a 30 & 9 & 16.9 & 15 & 24.6 & $0.5677^{1}$ \\
\hline 31 a 50 & 27 & 50.9 & 30 & 49.2 & \\
\hline Without a partner & 28 & 52.8 & 22 & 36.1 & $0.0919^{2}$ \\
\hline With a partner & 25 & 47.2 & 39 & 62.3 & \\
\hline \multicolumn{6}{|l|}{ Current occupation } \\
\hline Employed & 46 & 86.8 & 49 & 80.3 & $0.4301^{2}$ \\
\hline Yes & 45 & 84.9 & 48 & 78.7 & $0.4519^{2}$ \\
\hline No & 7 & 13.2 & 12 & 19.7 & \\
\hline Did not answer & 1 & 1.8 & 1 & 1.63 & \\
\hline
\end{tabular}

GMAMA — patients with suspected breast cancer; GPLAST — cosmetic surgery group

$\mathrm{p}^{1}=$ Chi-square test for tables greater than $2 \times 2 ; \mathrm{p}^{2}=$ Fisher Exact test 
According to the criteria established by the protocol $2,17,22,21$, the cutting points were:

- STAI I: mild anxiety: $\leq 35$; moderate anxiety: 36 to 46 ; severe anxiety: $\geq 47$.

- $\quad$ STAI II: mild anxiety: $\leq 32$; moderate anxiety: 33 to 41 ; severe anxiety: $\geq 42$.

Table II shows the mean, standard deviation median, $25^{\text {th }}$ and $75^{\text {th }}$ percentiles of STAI 1 and STAI II scores of GMAMA and GPLAST, and the results of the Mann-Whitney test.

There were statistically significant differences between GMAMA and GPLAST ( $p=0.0406$ ) when the scores of the STAI I were compared (Mann-Whitney test).
Table III shows the total number and percentage of patients with moderate, mild, and severe anxiety (STAI I and II) of both groups and the Mann-Whitney test.

There was a statistically significant difference $(p=0.043)$ in the prevalence of the different levels of anxiety-state (STAI I) between Gmama and Gplast (Mann-Whitney test).

There were no statistically significant differences $(p=0.776)$ in the prevalence of the different levels of anxiety-trait (STAI II) between both groups (Mann-Whitney test).

Each socio-demographic data and prior experience with surgical procedures in both groups were analyzed to determine the presence of risk factors for severe anxiety-state

Table II - Medians, and $25^{\text {th }}$ and $75^{\text {th }}$ Percentiles of the STAI I (anxiety-state) and STAI II (anxiety-trait) Scores in Both Groups

\begin{tabular}{|c|c|c|c|c|c|c|}
\hline & \multicolumn{3}{|c|}{ STAI I — State } & \multicolumn{3}{|c|}{ STAI II - Trace } \\
\hline & Gmama & GPLAST & $\mathrm{p}$ & Gmama & GPLAST & $p$ \\
\hline Mean \pm SD & $42.3 \pm 7.7$ & $38.0 \pm 8.2$ & & $39.1 \pm 8.1$ & $37.6 \pm 8.3$ & \\
\hline Median & 42.0 & 38.0 & 0.0406 & 39.5 & 36.0 & 0.7843 \\
\hline $25^{\text {th }}$ percentile & 37.0 & 33.0 & & 32.0 & 33.0 & \\
\hline $75^{\text {th }}$ percentile & 48.0 & 44.0 & & 42.2 & 41.0 & \\
\hline
\end{tabular}

GMAMA — patients with suspected breast cancer; GPLAST — cosmetic surgery group $p=$ Mann-Whitney test

Table III - Total Number and Percentage of Patients with Mild, Moderate, and Severe Anxiety-State in Both Groups According to the STAI I

\begin{tabular}{|c|c|c|c|c|}
\hline \multirow[b]{2}{*}{ STAI I } & \multicolumn{2}{|c|}{ Gmama } & \multicolumn{2}{|c|}{ GPLAst } \\
\hline & Total number & $\%$ & Total number & $\%$ \\
\hline$\leq 35$ (mild anxiety) & 10 & 18.9 & 23 & 37.7 \\
\hline$\geq 47$ (severe anxiety) & 19 & 35.8 & 12 & 19.7 \\
\hline total & 53 & 100.0 & 61 & 100.0 \\
\hline
\end{tabular}

GMAMA — patients with suspected breast cancer; GPLAST — cosmetic surgery group $\mathrm{p}=$ Mann-Whitney test

Table IV - Total Number and Percentage of Patients with Mild, Moderate, and Severe Anxiety-Trait in Both Groups According to the STAI II

\begin{tabular}{|c|c|c|c|c|}
\hline \multirow[b]{2}{*}{ STAI II } & \multicolumn{2}{|c|}{ GMAmA } & \multicolumn{2}{|c|}{ GPLAST } \\
\hline & Total number & $\%$ & Total number & $\%$ \\
\hline$\leq 32$ (mild anxiety) & 14 & 26.4 & 15 & 24.6 \\
\hline $33-41$ (moderate anxiety) & 24 & 45.3 & 31 & 50.8 \\
\hline$\geq 42$ (severe anxiety) & 15 & 28.3 & 15 & 24.6 \\
\hline Total & 53 & 100.0 & 61 & 100.0 \\
\hline$p=0.832$ & & & & \\
\hline
\end{tabular}

GMAMA - patients with suspected breast cancer; GPLAST - cosmetic surgery group $p=$ Mann-Whitney test 
(STAI I). There were no statistically significant differences regarding the prevalence of severe anxiety-state for anyone of the variables analyzed in both groups.

\section{DISCUSSION}

"Fear of the unknown" 2,22,24 has been deemed the greatest source of anxiety among patients at the outpatient basis preanesthetic evaluation. However, the specific evaluation of anxiety, as a separate item, is not part of the routine outpatient and inpatient basis APA. Therefore, special situations in which the mood of the patients might be altered, by the disease and/or other reasons (family problems, pre-school age children, possibility of mutilation) go unnoticed by the anesthetic-surgical team ${ }^{2,4,25-27}$.

The STAI was chosen in this study due to the quality of the tool (self-evaluation and easily understood by the lay person), and because it is considered the golden standard 20,21,23,28-37. The mean values of anxiety state and trait (STAI I and II) found in the present study are close to the values reported in the literature, in studies carried on in the preoperative period, but not at the time of the APA ${ }^{2,6,38}$.

In this study, the prevalence of moderate and severe anxiety was $89.1 \%$ in GMAMA and $62.3 \%$ in GPLAST, which are elevated in both groups, reflecting the importance of the APA, close to the surgery. It also demonstrated, as it was identified in the statistical analysis, that the prevalence of severe anxiety was higher in GMAMA than in GPLAST, suggesting that the imminence of a cancer diagnosis induces more frequently a high level of anxiety than a cosmetic surgery.

The results did not show any difference in anxiety-trait in both groups, as would be expected, since it reflects a stable tendency of the individual regarding anxiety, which is less sensible to changes regarding environmental situations ${ }^{39}$.

Follow-up studies with breast cancer patients who underwent mastectomy reported abnormal anxiety levels in $20 \%$ to $25 \%$ of the patients ${ }^{40,41}$.

Magalhães Filho et al. ${ }^{7}$ found a $40.6 \%$ prevalence of anxiety in patients with different types of cancer evaluated by the hospital anxiety and depression scale (HAD) at the APA.

The results obtained in the present study in the group of patients with suspected breast cancer, regarding the prevalence of anxiety, are within the range of values reported in the literature, using several methods, for cancer patients undergoing clinical treatment and patients with and without cancer in the preoperative period; it is also important to stress that neither one of those studies evaluated patients at the time of the outpatient basis APA ${ }^{2,6,12}$.

The study of Yumi et al. ${ }^{42}$ comparing the state of anxiety in patients who underwent removal of a breast tumor, demonstrated that patients who repressed their preoperative anxiety showed a higher level of anxiety, depression, and confusion after receiving the diagnosis of cancer than the group of patients who openly expressed their emotions. The present study did not evaluate the level of anxiety of the patients after the diagnosis of cancer, which leaves space for further studies.

There were no comparative data in the literature regarding the group of patients scheduled for cosmetic surgery.

Smith et al. ${ }^{43}$ verified that the anxiety-trait, more than the anxiety-state, affects the intraoperative anesthetic needs and suggested that anesthesiologists should base anesthetic induction on the preoperative anxiety level of the patients. Those aspects were not evaluated in this study.

It was not possible to identify risk factors for severe anxiety. These results do not coincide with those found in the literature that report higher prevalence of anxiety in younger patients, with low schooling, higher income, and without a partner ${ }^{6,44-48}$. However, the data in the literature refers to the comparison among patients with and without anxiety and the present study compares different levels of anxiety.

We need a new APA model, more concerned with the psychosocial dimensions of the patients and, therefore, allowing for better diagnosis and treatment of anxiety disorders. The advantage of a broad and early approach of the patient in the preoperative period is that it allows us to detect individuals with anxiety disorders, whose consequences can be seen both in the intra- and postoperative periods. The approach and treatment of those patients should be further studied, since the clinical treatment can be greatly improved by detecting the emotional concerns of the patients.

This study demonstrated the importance of adding the evaluation of the degree of anxiety to the preanesthetic evaluation of patients with suspected breast cancer.

\section{REFERÊNCIAS - REFERENCES}

01. Ramsay MA - A survey of pre-operative fear. Anaesthesia, 1972;27:396-402.

02. Maranets I, Kain ZN - Preoperative anxiety and intraoperative anesthetic requirements. Anesth Analg, 1999;89:1346-1351.

03. Roizen MF, Foos JF, Fischer SP — Preoperative Evaluation, em: Miller RD - Anesthesia, $5^{\text {th }}$ Ed, Churchill Livingston, 2000;824883.

04. Kraft $\mathrm{M}-$ Holistic issues in the preoperative period. Int Anesthesiol Clin, 2002;40:201-212.

05. Mackenzie JW - Daycase anaesthesia and anxiety. A study of anxiety profiles amongst patients attending a day bed unit. Anaesthesia, 1989;44:437-440.

06. Caumo W, Schmidt AP, Schneider CN et al. - Risk factors for preoperative anxiety in adults. Acta Anaesthesiol Scand, 2001;45:298-307.

07. Magalhães Filho LL, Segurado A, Marcolino AM et al. — Impacto da avaliação pré-anestésica sobre a ansiedade e depressão dos pacientes cirúrgicos com câncer. Rev Bras Anestesiol, 2006;56:126-136.

08. Schag CA, Heinrich RL - Anxiety in medical situations: adult cancer patients. J Clin Psychol, 1989;45:20-27.

09. Razavi D, Stiefel F - Common psychiatric disorders in cancer patients. I. Adjustment disorders and depressive disorders. Support Care Cancer, 1994;2:223-232. 
10. Breitbart $\mathrm{W}$ - Identifying patients at risk for, and treatment of major psychiatric complications of cancer. Support Care Cancer, 1995;3:45-60.

11. Ballone GJ - Ansiedade no paciente com câncer. Disponível em: Psiqweb. http://gballone.sites.uol.com.br/psicossomatica/ cancer2.html. Acesso em 26 out 2004.

12. Carroll BT, Kathol RG, Noyes RJ et al. - Screening for depression and anxiety in cancer patients using the hospital anxiety and depression scale. Gen Hosp Psychiatry, 1993;15:69-74.

13. DeVita V - Cancer Principles and Practice of Oncology. $6^{\text {th }} \mathrm{Ed}$, Lippincott-Raven, 2001.

14. Greene FL, Page DL, Fleming ID et al. - AJCC Cancer Staging Manual, 6 $6^{\text {th }}$ Ed. New York, Springer-Verlag, 2002.

15. Honigman RJ, Phillips KA, Castle DJ - A review of psychosocial outcomes for patients seeking cosmetic surgery. Plast Reconstr Surg, 2004;113:1229-1237.

16. Assad A, Verçosa N - Preparo Pré-Operatório, em: Cavalcanti I, Cantinho FAF, Assad AR - Anestesia para Cirurgia Plástica. SAERJ, 2005;13-25.

17. Spielberger $C D$ - Manual for the State-Trait Anxiety Inventory (STAI: Form Y). Palo Alto, CA, Consulting Psychologists, 1983.

18. Biaggio AMB, Natalício $L$ - Tradução e Adaptação do Manual de Psicologia Aplicada - IDATE — Rio de Janeiro, 1979.

19. Millar K, Jelicic M, Bonke B et al. - Assessment of preoperative anxiety: comparison of measures in patients awaiting surgery for breast cancer. Br J Anaesth, 1995;74:180-183.

20. Granot, M, Ferber SG - The roles of pain catastrophizing and anxiety in the prediction of postoperative pain intensity: a prospective study. Clin J Pain, 2005;21:439-445.

21. Noto $Y$, Sato T, Kudo $M$ et al. - The relationship between salivary biomarkers and state-trait anxiety inventory score under mental arithmetic stress: a pilot study. Anesth Analg, 2005; 101:1873-1876.

22. Johnston M. Anxiety in surgical patients. Psychol Med, 1980; 10:145-52.

23. Kain ZN, Mayes LC, Cicchetti DV et al. - The Yale Preoperative Anxiety Scale: How does it compare with a "gold standard". Anesth Analg, 1997;85:783-788.

24. Macuco MV, Macuco OC, Bedin A et al. - Efeito de um consultório de anestesiologia sobre as preocupações, percepções e preferências relacionadas à anestesia. Comparação entre o sexo masculino e feminino. Rev Bras Anestesiol,1999;49:179189.

25. Bottomley A - Psychosocial problems in cancer care: a brief review of common problems. J Psych Mental Health Nurs, 1997;4:323-331.

26. Braz DS, Ribas MM, Dedivitis RA et al. - Quality of life and depression in patients undergoing total and partial laryngectomy. Clinics (São Paulo), 2005;60:135-142.

27. Mathias LAST, Guaratini AA - Avaliação Pré-Anestésica, em Duarte NMC, Bagatini A, Anzoategui LC - Curso de Educação à Distância em Anestesiologia. São Paulo, Segmento Farma, 2005;15-29.

28. Spielberger $C D-$ Manual for the State-Trait Anxiety Inventory for Children. Palo Alto, CA, Consulting Psychologists, 1973.

29. Holm L, Fitzmaurice $L-$ Factors influencing parent anxiety levels in a pediatric emergency department waiting area. Pediatr Res, 2004;56:672.

30. Moro ET, Módolo NSP — Ansiedade, a criança e os pais. Rev Bras Anestesiol, 2004;54:728-738.

31. Astin F, Jones K, Thompson DR - Prevalence and patterns of anxiety and depression in patients undergoing elective percutaneous transluminal coronary angioplasty. Heart Lung, 2005;34:393-401.
32. Hsu YW, Somma J, Hung YC et al. - Predicting postoperative pain by preoperative pressure pain assessment. Anesthesiology, 2005;103:613-618.

33. Padmanabhan R, Hildreth AJ, Laws D - A prospective, randomised, controlled study examining binaural beat audio and preoperative anxiety in patients undergoing general anaesthesia for day case surgery. Anaesthesia, 2005; 60:874-877.

34. Schupp CJ, Berbaum K, Berbaum M et al. - Pain and anxiety during interventional radiologic procedures: effect of patients' state anxiety at baseline and modulation by nonpharmacologic analgesia adjuncts. J Vasc Interv Radiol, 2005;16:1585-1592.

35. Van den Bosch JE, Moons KG, Bonsel GJ et al. - Does measurement of preoperative anxiety have added value for predicting postoperative nausea and vomiting? Anesth Analg, 2005;100:1525-1532.

36. Wang S-M, Gaal D, Maranets I et al. - Acupressure and preoperative parental anxiety: a pilot study. Anesth Analg, 2005; 101:666-669.

37. Pan $\mathrm{PH}$, Coghill $\mathrm{R}$, Houle TT et al. - Multifactorial preoperative predictors for postcesarean section pain and analgesic requirement. Anesthesiology, 2006;104:417-425.

38. Iwamitsu, Y, Shimoda K, Abe HT et al. — Differences in emotional distress between breast tumor patients with emotional inhibition and those with emotional expression. Psychiatry Clin Neurosci, 2003;57:289-94.

39. Nardi AE - Comentários do debatedor: escalas de avaliação de ansiedade. Rev Psiq Clin, 1998;25:331-333.

40. Morris T, Greer HS, White P - Psychological and social adjustment to mastectomy: a two year follow-up study. Cancer, 1977; 40:2381-2387

41. Maguire GP, Julier DL, Hawton KE et al. - Psychiatric morbidity and referral on two general medical wards. Br Med J, 1978; 1:268-270.

42. Yumi I, Kazutaka S, Hajime A et al. - The relation between negative emotional suppression and emotional distress in breast cancer diagnosis and treatment. Health Commun, 2005;18:201215.

43. Smith I, White PF, Nathanson M et al. - Propofol: an update on its clinical use. Anesthesiology, 1994; 81:1005-1043.

44. Dean C - Psychiatric morbidity following mastectomy: preoperative predictors and types of illness. J Psychosom Res, 1987; 31:385-392.

45. Palapattu GS, Haisfield-Wolfe ME, Walker JM et al. - Assessment of perioperative psychological distress in patients undergoing radical cystectomy for bladder cancer. J Urol, 2004;172:1814-1817.

46. Smith AB, Selby PJ, Velikova G et al. - Factor analysis of the Hospital Anxiety and Depression scale from a large cancer population. Psychol Psychother, 2002;75:165-176.

47. Burgess C, Cornelius V, Love S et al. - Depression and anxiety in women with early breast cancer: five year observational cohort study. BMJ, 2005;330:702-710.

48. Sarna L, Brown JK, Cooley ME et al. - Quality of life and meaning of illness of women with lung cancer. Oncol Nurs Forum, 2005;32:E9-19.

\section{RESUMEN}

Alves MLM, Pimentel AJ, Guaratini AA, Marcolino JAM, Gozzani JL, Mathias LAST - Ansiedad en el Período Preoperatorio de Cirugías de Mama: Estudio Comparativo entre Pacientes con Sospecha de Cáncer a ser Sometidas a Procedimientos Quirúrgicos Estéticos.

JUSTIFICATIVA Y OBJETIVOS: La evaluación de la ansiedad no forma parte de la rutina de la evaluación preanestésica (APA), lo que hace que situaciones especiales en que el estado emocional 
de los pacientes pueda estar alterado pasen desapercibidas por el anestesiólogo. Este estudio quiso comparar al momento de la APA ambulatorial, factores de riesgo, intensidad y prevalencia de ansiedad en pacientes con sospecha de cáncer de mama a ser sometidas a procedimientos quirúrgicos estéticos de mama.

MÉTODO: Después de la aprobación por el Comité de Ética, fueron estudiadas en el ambulatorio de APA, 114 pacientes, ASA I o II, edad $\geq 14$ años, divididas en los grupos: Gmama — pacientes con sospecha de cáncer de mama; GPLAST — pacientes a ser sometidas a cirugía plástica estética. Después del consentimiento aclarado, las pacientes respondieron al la prueba de evaluación de ansiedad (IDATE - Inventario de Ansiedad Trazo-Estado) antes de la evaluación preanestésica. Se analizaron: datos sociodemográficos; experiencia con procedimientos quirúrgicos anteriores; número y porcentaje de pacientes con ansiedad baja, moderada y alta (IDATE I y II); promedio de los puntajes de las escalas IDATE I y II.

RESULTADOS: Los grupos fueron homogéneos en relación a los datos sociodemográficos y experiencia con procedimientos quirúrgicos anteriores. Se observó diferencia significativa de los niveles y prevalencia de ansiedad-estado (IDATE I). No fueron identificados factores de riesgo para ansiedad-estado y ansiedad-trazo.

CONCLUSIONES: Las pacientes con sospecha de cáncer de mama a ser sometidas a la retirada de nódulo o tejido mamario para diagnóstico presentaron niveles y prevalencia de ansiedad-estado alta mayores que las pacientes a ser sometidas a mamoplastías; los niveles y la prevalencia de ansiedad-trazo fueron similares en los de los grupos y no fueron identificados factores de riesgo para ansiedad-estado y ansiedad-trazo. 